Article

\title{
Interrelationships of Land Use/Cover Change and Topography with Soil Acidity and Salinity as Indicators of Land Degradation
}

\author{
Ramita Manandhar ${ }^{1, *}$ and Inakwu O. A. Odeh ${ }^{2}$ \\ 1 Agriculture Biodiversity Section, Food Security and Environment Division, \\ Ministry of Agriculture Development, Singha Durbar, Kathmandu 44600, Nepal \\ 2 Department of Environmental Sciences, Faculty of Agriculture and Environment, The University of \\ Sydney, Sydney, NSW 2006, Australia; E-Mail: inakwu.odeh@sydney.edu.au \\ * Author to whom correspondence should be addressed; E-Mail: ramitaman@yahoo.com; \\ Tel.: +977-1-4211-940; Fax: +977-1-4211-935.
}

Received: 31 December 2013; in revised form: 21 January 2014 / Accepted: 10 February 2014 / Published: 13 March 2014

\begin{abstract}
As soil is the basis of all terrestrial ecosystems, degraded soil means lower fertility, reduced biodiversity and reduced human welfare. Therefore the focus of this paper is on elucidating the influence of land use and land cover (LULC) change on two important soil quality indicators that are fundamental to effective measures for ameliorating soil degradation; namely soil acidity and soil salinity in the Lower Hunter Valley of New South Wales, Australia. First, Analysis of Variance was used to elucidate the effects of LULC categories on soil acidity and salinity. The results indicate that soils under Vineyard have significantly higher $\mathrm{pH}$. In contrast there is no significant effect of LULC or its change on soil salinity. To further elucidate the complex interactions of these soil quality indicators with landscape attributes over 20 years and other terrain attributes, multivariate ordination techniques (correspondence analysis and canonical correspondence analysis) were used. The results show that elevation exerted a more dominant influence on $\mathrm{pH}$ than the LULC types and their dynamics. In comparison, salinity of the soil appears to be higher in subsoil layers under woodland than under other LULC categories. The environmental implications of these interactions, as evidenced by this study, provide some insights for future land use planning in the region.
\end{abstract}

Keywords: soil salinity; soil acidity; canonical correspondence analysis; ANOVA; land use and land cover change; landform attributes 


\section{Introduction}

Land use and land cover change (LUCC) has been recognized as a major driving force of global environmental perturbations. Through human history, land surface cover has been altered through land clearing of natural forests, subsistence agriculture, intensification of farmland production, modification of rangeland and urbanisation. The consequence of this change in the natural land cover is the modification of the world's landscape in pervasive ways [1,2], in spite of the positive outcomes of LUCC in terms of increased food and fibre production to meet the increasing needs of world's growing population. As such LUCC has brought about unpleasant consequences such as global and regional climate change, distressed global biogeochemical cycles (e.g., carbon, nitrogen, and water cycles), declining biodiversity and soil degradation. As soil is the basis of all terrestrial ecosystems, degraded soil means lower fertility, reduced biodiversity and reduced human welfare [3]. Thus, protecting soils from such degradation is extremely important to providing safe and sound habitat for the future generations. Therefore the focus of this paper is on elucidating the influence of LUCC on two important soil quality indicators that are fundamental to effective measures for ameliorating soil degradation; namely soil acidity and soil salinity.

It is well known that soil acidity is caused by acidification as a natural process via mineral weathering in the presence of a continuous input of very dilute carbonic acid, followed by the leaching of the weathering products [4]. However, accelerated acidification occurs when soil is exploited for agriculture, especially under intensive systems where large amounts of $\mathrm{N}$ are recycled through the system, and when substantial amounts of organic products and residues are removed [4,5]. Acid soils are infertile through a number of mechanisms which restrict plant growth: (i) there is increase in concentration of toxic elements such as aluminium and manganese in the soil solution; (ii) as a consequence essential nutrients, such as $\mathrm{Ca}, \mathrm{Mg}, \mathrm{K}$, are displaced and leached from the root zone; and (iii) other nutrients like $\mathrm{P}$ and Mo are made less available to plant roots. Such soils with high soil reaction are estimated to cover approximately $40 \%$ of the land area in Australia [5], where accelerated acidification has been reported to be more widespread than salinity, especially in the southeastern regions of Australia where the study region is located. About 18 million ha of the agriculturally

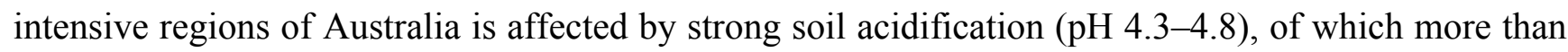
a quarter of the affected areas (5 to 7 million ha) exists in New South Wales [6]. For sustainable management of acidic soils, at least in agricultural production systems and ultimately for economic and social sustainability, the panacea to acidification in farming systems is to apply a neutralizing agent such as lime. The question then is, under the agricultural production systems, how do the opposing effects of soil acidification and liming determine ultimate soil acidity?

Like sodicity, soil salinization is another important land degradation process that limits crop production. Soil salinization, which is as a result of accretion of $\mathrm{Na}^{+}, \mathrm{Cl}^{-}, \mathrm{Mg}^{2+}$ and $\mathrm{SO}_{4}{ }^{2-}$ ions in soils, is recognised as the major cause of downfall of past civilisations [7]. In Australia, saline soils with the prevalence of sodium salts constitute about $30 \%$ of the land area [7]. Out of this, dryland salinity is one of the most serious environmental and resource management problems in the country [8]. Dryland salinity is mainly a function of rising groundwater tables, caused by increased recharge following replacement of native vegetation with annual/pasture systems [9]. As such salts deposited below ground are brought to the surface causing damage to agricultural production and infrastructure, 
and contaminating streams. A report published by the Australian Natural Resource Atlas [10] estimated that about 5.7 million ha of Australia have a high potential for developing dryland salinity through shallow water tables, with this is expected to rise to 17 million ha by 2050 . Similarly, the National Dryland Salinity Program [11] projected the cost of dryland salinity will increase by $60-70$ percent over the following 20 years.

If soil acidity and salinity are to be managed effectively, their causes and behaviour, vis-à-vis management practices, must be understood. The monitoring of soil acidity and salinity through understanding of their properties as influenced by LUCC is important, as these soil quality indicators are good indicators of soil productivity. Additionally, these quality indicators are particularly prone to change in short time spans. Specifically the influence of LUCC on these quality indicators has special relevance in the Lower Hunter Valley which has experienced rapid land use change in the last 20 years. Salinity and acidity problems in the area have been reported by a number of studies [12-14]. Salinity, in particular, has been a problem in the Hunter Valley since it was first settled in early 1800s as recorded by early explorers who noted high salinity levels in creeks around the Bayswater area [15]. Human activities, such as agriculture, mining and power generation, have exacerbated this problem resulting in more than 50,000 hectares of land affected by dryland salinity in the Valley [12].

Based on the foregoing discourse, the aim of this paper is to test the two hypotheses that:

LUCC has no significant influence on soil acidity/salinity in the lower Hunter valley.

The soil acidity and salinity interactions with LUCC can be differentiated from interactions with other landscape features such as landscape processes influencing soil acidity/salinity; in other words landform attributes combined with LUCC can better explain the spatial patterns of soil acidity/salinity.

To test the first hypothesis, the widely used analysis of variance (ANOVA) was performed on LULC categories in relation to soil $\mathrm{pH}$ and electrical conductivity (EC1:5) as measured using 1:5 soil: water suspension. The second hypothesis was tested by performing multivariate ordination analysis to unravel the complex interrelationships of the landform attributes and LULC derivatives with soil $\mathrm{pH}$ and EC1:5. However, before proceeding to these analyses a brief review of the statistical methods is covered.

There exist both simple and multivariate approaches that could be used to decipher the influence of LUCC on soil patterns or soil quality. Simple statistical techniques, such as regression, correlation analysis and ANOVA, are commonly used to study the effect LULC change on soil properties $[16,17]$. For example the one-way ANOVA table could be used to summarise the response information for each level of the nominal or ordinal factor-which could be a land use/land cover category. One-way ANOVA can also be used for multiple comparisons to test differences among group means, whereby student's $t$ test, are required for pair-wise comparisons.

When confronted by more complex situations in which there are two or more target response variables and a set of explanatory or predictor variables, methods such as simple/multiple regression analysis or one-way ANOVA, or even MANOVA, may not be robust in elucidation the interrelationships. These methods cannot provide a broad overview of how soil properties behave in relation to the combined effects of the predictor variables. For example while the transient soil quality indicators, such as acidity and salinity, are greatly influenced by the terrain attributes, namely: digital elevation model (DEM), slope, compound topographic index, etc. [18-20], it is important to deconstruct the influence of land use/cover on these indicators from the complex interactions with the 
terrain attributes. It could be more informative and economical to handle the two sets of data all simultaneously using direct or indirect gradient techniques [21], by including the terrain attributes in the analysis. In such cases, multivariate ordination gradient techniques have been recommended as more appropriate for exploring the complex interrelationships between a set of explanatory attributes on one hand and another set of target variables [22-28]. Moreover, LULC attributes or factors are qualitative in nature, and as such are not amenable to or meets the assumptions of the classical ANOVA or regression analysis. ANOVA requires a number of assumptions to hold true such as independence of observation, linearity, and additivity of effects, homogeneity of variance, normally distributed errors $[29,30]$. As these assumptions are not met in many situations, robust multivariate techniques such as CA (correspondence analysis) and CCA (canonical correspondence analysis) have been recommended as they do not require meeting these stringent assumptions.

CA and CCA techniques are powerful tools for investigating and summarizing underlying trends in complex data structures [31]. The techniques have been widely applied in species environment relationship $[22,23,28]$. CA, as one of the popular indirect gradient ordination techniques in ecology [22,31], uses the efficient reciprocal weighted averaging algorithm. The technique is an indirect gradient ordination technique because it is followed by environmental gradient identification [22]. In contrast CCA as a direct gradient technique is a canonical form of CA in which the site scores are restricted to be linear combination of measured environmental variables. Although, these methods have potential to be applied in soil-environment studies in order to understand a complex relationship, only a few studies [18,32,33] have applied these techniques to soil studies. No single study to our knowledge has included land use/land cover factor in an environmental gradient analysis. This paper is aimed at exploring this possibility.

\section{Materials and Methods}

\subsection{Data Requirements}

\subsubsection{Land Use/Land Cover Data}

In this paper the historical LULC images, covering the study region for 1985, 1991, 1995, 2000 and 2005, were used to decipher the patterns of LU/LC change and to explore the effect of LUCC on soil acidity/salinity. Detailed description on how LULC images were obtained can be found in Manandhar et al. [34].

\subsubsection{Soil Quality Indicators Data}

Soil samples were collected using a Latin hypercube sampling scheme [35,36]. Thus the scheme used is based on a stratified random procedure which provides an efficient way of sampling from the multivariate distribution of the covariates, as it covers a full range of each covariate by maximally stratifying the marginal distribution. Based on this scheme 246 soil sample locations were selected (Figure 1). At each location soil samples were collected at predetermined depths: 0-10, 10-20, 20-30, 40-50 and 60-100 cm. After oven drying at $105^{\circ} \mathrm{C}$, each sample was ground and fine earth separated through a 2-mm diameter sieve. The electrical conductivity and $\mathrm{pH}$ of each sample were measured in a 
1:5 soil: water suspension after $30 \mathrm{~min}$ of shaking, the $\mathrm{pH}$ and Electrical Conductivity (EC) measurements were done using $\mathrm{pH}$ and EC meters respectively [36].

Figure 1. Location of the study area in New South Wales, Australia, showing soil sample sites as red dots. Note: the thin grey lines are the suburb boundaries.

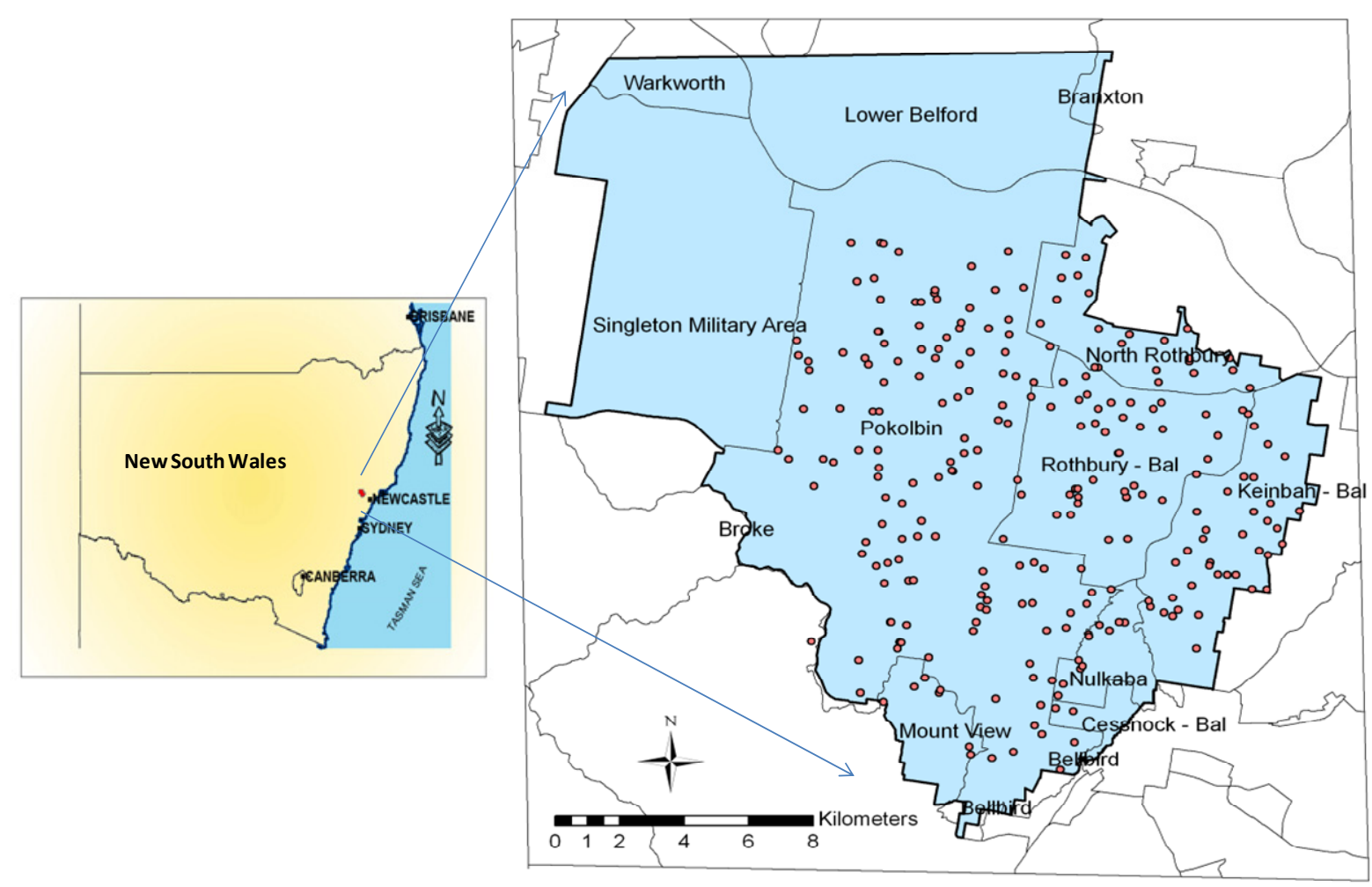

\subsubsection{Derivation of Topographic Attributes}

The topographic attributes that would potentially have influence on the two soil quality indicator values include digital elevation model (DEM) and its derivatives-slope, upslope area $\left(A_{i}\right)$ and compound topographic index (CTI). These attributes have been observed to influence a number of soil properties $[18,37,38]$. Large CTI values, usually found in lower part of a watershed and convergent hollows associated with gentle slopes and/or soils that are characterised by low hydraulic conductivity, are indicative of increased likelihood of saturated conditions [36]. The DEM of the study region was obtained from the then New South Wales Department of Natural Resources (DNR). As a generic attribute, the DEM was used to derive the following topographic attributes which are deemed influential on soil acidification and salinization processes, using SAGA GIS tools.

Slope, as an important attribute controlling the flux of materials within the landscape, is an important controlling feature in hydrological and geomorphological processes. It can be defined as the rate of change of elevation down the steepest descent across a point in the landscape [39]. Slope can be derived in either degree or as gradient (decimal or in per cent). For the purpose of this study, slope was derived in degree from the DEM, using the slope function within the SAGA GIS environment.

Specific contributing area: Upslope contributing area (A) can be computed as the total area above a point or a certain length of contour that contribute flow to the point or across the contour [39]. More appropriate for this study is the specific contributing area, $A_{s}$, which is the ratio of the contributing area 
and the contour length, $\mathrm{A} / 1$. In calculating $A_{s}$ from a gridded DEM, the contour length was assumed to be approximately the size of a grid cell; in the simplest case the contributing area was determined by the number of cells contributing flow to a cell [39]. Upslope contributing area is an important landform attribute that measures or approximates the quantity of water that passes through a point or across a contour length.

Compound topographic wetness index (CTI) was derived using the equation:

$$
C T I=\ln \left(\frac{A_{s}}{\tan \beta}\right)
$$

where $A_{s}$ is the specific upslope contributing area as described above and $\beta$ is slope in degrees. CTI represents the topographic control on soil wetness, based on a number of assumptions listed elsewhere [39].

\subsubsection{Derivation of LULC and Terrain Attributes for Soil Sampling Points}

Ground co-ordinate points from where soil samples were collected (Figure 1), were overlain on LULC maps using ArcGIS (ESRI, 2009) from which the historical LULC information for each point was obtained. The derived terrain attributes (elevation, slope and CTI) were also overlain on the LULC maps and their values were then obtained for each soil sampling points.

\subsection{Assessing the Effect of Land Use/Land Cover Change on Soil pH and Salinity}

In the first instance, the effects of LUCC on soil acidity and salinity were each tested using ANOVA. The latter is used here as an attribution and tests the part of the total variability in a response which is due to the differences in mean responses among the LULC categories. The ANOVA was performed to test if LULC indices, shown in Table 1, had significant impact on soil acidity/salinity. While untransformed $\mathrm{pH}$ values were used for the analysis, EC values were log-transformed prior to ANOVA in order to meet the requirement of normality of distribution. Pair-wise comparison was then performed using student's $t$ test to determine if the mean value of a given category is significantly different from the mean of every other category.

\subsection{Multivariate Analysis of Interrelationships of the Soil Quality Indicators with Landform Attributes and Land Use Covariates}

Out of the various multivariate ordination techniques used in environmental studies, principal component analysis (PCA), correspondence analysis (CA), redundancy analysis (RDA) and canonical correspondence analysis (CCA) were initially tested. Based on percentage variance accounted for in the target variable-environment interactions by the resulting ordination axes, CA and CCA were chosen for further analysis as they have variance distributed more or less uniformly across the first few axes. CA, as a popular ordination technique in ecology [22,31], uses an efficient reciprocal weighed averaging algorithm based on the non-monotonic Gaussian species response models. Thus, CA is an indirect gradient analysis technique while CCA is a canonical form of CA in which the site scores are restricted to be linear combinations of the environmental variables [18,22]. In ecology, CA extracts continuous axes of variation from species occurrences or abundance data, typically interpreted with the 
help of external knowledge and data on environmental variables; this two-step approach (ordination followed by environmental gradient identification), is termed as indirect gradient analysis [22]. The eigenvalues in CCA are usually smaller than those in CA because of the restrictions imposed on the site scores in CCA.

Table 1. Description of land use and land cover (LULC) abbreviations.

\begin{tabular}{ll}
\hline Abbreviation & \\
\hline Wood_C & Woodland consistency, i.e., Woodland throughout the accounting period 1985 to 2005. \\
Past_C & Pasture/scrubland consistency, i.e., Pasture/scrubland throughout the accounting period \\
Vine_C & Vineyard consistency i.e., Vineyard throughout the accounting period 1985 to 2005. \\
F91vine & Area converted to Vineyard between 1985 and 1991. \\
F95vine & Area converted to Vineyard between 1991 and 1995. \\
F2000vine & Area converted to Vineyard between 1995 and 2000. \\
F05vine & Area converted to Vineyard between 2000 and 2005. \\
Aforest & Area converted to Woodland, i.e., Pasture/scrubland in earlier maps but Woodland in the \\
& final map \\
Wood2 past & Area converted from Woodland to Pasture/scrubland, i.e., Woodland in earlier maps but \\
Others & Pasture/scrubland in the final map \\
pH10 & Other than above, such as Vineyard converting to Pasture/scrubland, or Built-up area etc. \\
pH20 & pH of soil from a depth of $0-10 \mathrm{~cm}$ \\
pH30 & pH of soil from a depth of $10-20 \mathrm{~cm}$ \\
pH50 & pH of soil from a depth of $20-30 \mathrm{~cm}$ \\
EC10 & pH of soil from a depth of $40-50 \mathrm{~cm}$ \\
EC20 & EC of soil from a depth of $0-10 \mathrm{~cm}$ \\
EC30 & EC of soil from a depth of $10-20 \mathrm{~cm}$ \\
EC50 & EC of soil from a depth of $20-30 \mathrm{~cm}$ \\
& EC of soil from a depth of $40-50 \mathrm{~cm}$
\end{tabular}

In order to incorporate the influence of LUCC on the soil quality indicators over the period between 1985 and 2005, several types of new LULC dynamic indicators (Table 1) were derived from the series of LULC maps. For example, Vineyard consistency (Vine_C) = area that remains as vineyard throughout the accounting period (1991-2005); Pasture/scrubland consistency (Past_C) = area that remains as pasture/scrubland throughout the accounting period (1991-2005); F95vine = area that was converted from other LULC types to vineyard between 1991 and 1995 and Aforest = Area converted to woodland between 1991 and 1995 or 2005 . These indices were derived as nominal data for every sample location, with 1 representing true and zero not.

The CA and CCA were carried out using a FORTRAN program (CANOCO version 4.5), written by [40]. The selected soil properties ( $\mathrm{pH}$ and EC) are the target variables and LULC categories, along with the indices derived above, and the landform attributes (DEM, Slope, and CTI) were the environmental (explanatory) variables used. The list of LULC and other landform attributes and soil parameters used for derivation CA and CCA are shown in Table 1. The transition indices (conversion of one LULC to another during the accounting period, also shown in Table 1) were not used for CA and CCA due to their high correlation with the derived consistency indices and the resultant inflation 
factors. Biplots of both CA and CCA were obtained to display the complex interrelationships between the soil quality indicators on one hand, and topographic attributes and LULC types on the other. In the biplots the predictor (LULC and topographic) variables are represented by arrows and soil variables are represented by points. The ordination diagram, as it is sometime referred to, shows the main pattern of variation in soil variables as accounted for by the predictor variables. Thus the complex relationships among the selected soil properties (soil $\mathrm{pH}$ and EC) and the predictor variables (LULC information, DEM, slope, CTI) can be elucidated. Topographic attributes-DEM, slope and CTI-were chosen because they are the natural attributes that affect most of the landscape processes such as filtration, runoff, soil reaction and salinization.

\section{Results and Discussion}

\subsection{Effects of LULC on Soil Acidity}

The ANOVA of $\mathrm{pH}$ in relation to LULC systems indicates a significant difference $(P=0.05)$ in $\mathrm{pH}$ values. Vineyard consistency (land area continuously under Vineyard since 1985) and F91vine (area converted to Vineyard between 1985 and 1991) are found to have higher $\mathrm{pH}$ value, significantly higher than that under Woodland consistency and Pasture/scrubland consistency (Table 2). This is specifically true for the topsoil $(0-10 \mathrm{~cm})$. Figure 2 illustrates the diamond plots of the $\mathrm{pH}$ versus different LULC consistencies for the different soil layers. The line across each diamond represents the group mean. The vertical span of each diamond represents the $95 \%$ confidence interval for each group, and the horizontal extent of each group along the $\mathrm{x}$-axis of diamond is proportional to the sample size for each category of the LULC [41].

Table 2. Mean $\mathrm{pH}$ values of soils under different land use and land cover (LULC) categories; values in brackets are the standard errors.

\begin{tabular}{|c|c|c|c|c|c|c|c|c|c|c|}
\hline Soil Parameter and Depth & $\begin{array}{c}\text { Wood_C } \\
n=59\end{array}$ & $\begin{array}{l}\text { Past_C } \\
n=108\end{array}$ & $\begin{array}{c}\text { Vine_C } \\
n=19\end{array}$ & $\begin{array}{c}\text { F91vine } \\
n=7\end{array}$ & $\begin{array}{c}\text { F95vine } \\
n=3\end{array}$ & $\begin{array}{l}\text { F2000vine } \\
n=9\end{array}$ & $\begin{array}{c}\text { F05vine } \\
n=3\end{array}$ & $\begin{array}{l}\text { Aforest } \\
n=18\end{array}$ & $\begin{array}{c}\text { Wood2past } \\
n=14\end{array}$ & $\begin{array}{l}\text { Others } \\
\qquad=8\end{array}$ \\
\hline pH10 & $\begin{array}{l}5.40 \mathrm{~d} \\
(0.08)\end{array}$ & $\begin{array}{l}5.61 \mathrm{c} \\
(0.06)\end{array}$ & $\begin{array}{l}6.75 \mathrm{a} \\
(0.14)\end{array}$ & $\begin{array}{l}6.53 \mathrm{a} \\
(0.23)\end{array}$ & $\begin{array}{l}6.57 \mathrm{ab} \\
(0.35)\end{array}$ & $\begin{array}{l}6.43 \mathrm{ab} \\
(0.20)\end{array}$ & $\begin{array}{c}5.66 \mathrm{bcd} \\
(0.35)\end{array}$ & $\begin{array}{l}5.50 \mathrm{~cd} \\
(0.14)\end{array}$ & $\begin{array}{c}5.57 \mathrm{~cd} \\
(0.16)\end{array}$ & $\begin{array}{l}5.76 \mathrm{~cd} \\
(0.22)\end{array}$ \\
\hline $\mathrm{pH} 20$ & $\begin{array}{l}5.46 \mathrm{c} \\
(0.08)\end{array}$ & $\begin{array}{l}5.90 \mathrm{~b} \\
(0.06)\end{array}$ & $\begin{array}{l}6.58 \mathrm{a} \\
(0.14)\end{array}$ & $\begin{array}{l}6.59 \mathrm{a} \\
(0.23)\end{array}$ & $\begin{array}{c}6.16 \mathrm{abc} \\
(0.35)\end{array}$ & $\begin{array}{l}6.16 \mathrm{ab} \\
(0.21)\end{array}$ & $\begin{array}{c}5.82 \mathrm{bc} \\
(0.35)\end{array}$ & $\begin{array}{l}5.71 \mathrm{bc} \\
(0.14)\end{array}$ & $\begin{array}{c}5.68 \mathrm{bc} \\
(0.16)\end{array}$ & $\begin{array}{c}5.81 \mathrm{bc} \\
(0.21)\end{array}$ \\
\hline $\mathrm{pH} 30$ & $\begin{array}{l}5.56 \mathrm{~d} \\
(0.08)\end{array}$ & $\begin{array}{l}6.03 \mathrm{bc} \\
(0.06)\end{array}$ & $\begin{array}{l}6.62 \mathrm{a} \\
(0.14)\end{array}$ & $\begin{array}{l}6.43 \mathrm{ab} \\
(0.24)\end{array}$ & $\begin{array}{c}6.01 \mathrm{abcd} \\
(0.37)\end{array}$ & $\begin{array}{c}5.63 \mathrm{~cd} \\
(0.21)\end{array}$ & $\begin{array}{c}5.94 \text { abcd } \\
(0.37)\end{array}$ & $\begin{array}{l}5.81 \mathrm{~cd} \\
(0.15)\end{array}$ & $\begin{array}{l}5.74 \mathrm{~cd} \\
(0.17)\end{array}$ & $\begin{array}{c}5.94 \text { bcd } \\
(0.24)\end{array}$ \\
\hline $\mathrm{pH} 50$ & $\begin{array}{l}5.32 \mathrm{~d} \\
(0.11)\end{array}$ & $\begin{array}{l}6.13 \mathrm{~b} \\
(0.08)\end{array}$ & $\begin{array}{l}6.72 \mathrm{a} \\
(0.20)\end{array}$ & $\begin{array}{c}6.24 \mathrm{abc} \\
(0.33)\end{array}$ & $\begin{array}{c}6.20 \text { abcde } \\
(0.50)\end{array}$ & $\begin{array}{l}5.26 \mathrm{de} \\
(0.29)\end{array}$ & $\begin{array}{c}5.94 \text { abcde } \\
(0.50)\end{array}$ & $\begin{array}{c}5.93 \text { bce } \\
(0.21)\end{array}$ & $\begin{array}{c}5.53 \text { cde } \\
(0.23)\end{array}$ & $\begin{array}{c}5.90 \text { bcde } \\
(0.31)\end{array}$ \\
\hline pHdeep & $\begin{array}{l}5.61 \mathrm{c} \\
(0.18)\end{array}$ & $\begin{array}{c}06.40 \mathrm{ab} \\
(0.14)\end{array}$ & $\begin{array}{l}6.87 \mathrm{a} \\
(0.31)\end{array}$ & $\begin{array}{l}6.74 \mathrm{ab} \\
(0.53)\end{array}$ & $\begin{array}{c}6.16 \mathrm{abc} \\
(0.81)\end{array}$ & $\begin{array}{c}5.53 \mathrm{bc} \\
(0.50)\end{array}$ & $\begin{array}{c}6.33 \mathrm{abc} \\
(0.81)\end{array}$ & $\begin{array}{c}6.03 \mathrm{abc} \\
(0.34)\end{array}$ & $\begin{array}{l}5.42 \mathrm{c} \\
(0.38)\end{array}$ & $\begin{array}{c}5.74 \mathrm{abc} \\
(0.53)\end{array}$ \\
\hline
\end{tabular}

Note: Comparisons are done across the rows. Levels not connected by same superscript letter are significantly different. Also note: Wood_C $=$ Woodland consistency, Past_C $=$ Pasture/scrubland consistency, Vine_C $=$ Vineyard Consistency, F91vine $=$ Area converted to Vineyard between 1985 and 1991, F95vine = Area converted to Vineyard between 1991 and 1995, F2000vine = Area converted to Vineyard between 1995 and 2000, and F05vine = Area converted to Vineyard between 2000 and 2005. Aforest = Area converted to Woodland, Wood2past $=$ Area converted from Woodland to Pasture/scrubland. Others $=$ other than previously stated. $\mathrm{pH} 10=\mathrm{pH}$ of soil at a depth of $0-10 \mathrm{~cm}, \mathrm{pH} 20=\mathrm{pH}$ of soil at a depth of $10-20 \mathrm{~cm}, \mathrm{pH} 30=\mathrm{pH}$ of soil at a depth of $20-30 \mathrm{~cm}, \mathrm{pH} 50=\mathrm{pH}$ of soil at a depth of $40-50 \mathrm{~cm}$ and $\mathrm{pHdeep}=\mathrm{pH}$ of soil at a depth $>50 \mathrm{~cm}$. 
The diamonds of F95vine (i.e., area converted to Vineyard between 1991 and 1995) and F05vine (area converted to Vineyard between 2000 and 2005) are horizontally narrow but vertically long, indicating they have very few observations with high variability. However, the diamond of Past_C (consistent Pasture/scrubland over the study period) has the largest number of observations as it constitutes the largest component of the landscape, and by chance has more soil samples. Wood_C (consistent Woodland) has similar pattern to the Past_C, as this constitutes the second largest component of the landscape. The circles on the right of the plots are indicative of pair-wise comparison means of each soil property under different LULC types. Circles for means that are significantly different either do not intersect or intersect slightly so that outside angle of intersection is less than 90 degrees (Figure 2a). If the circles intersect by an angle more than 90 degrees or they are nested, the means are said to be "not significantly different" Thus, the highlighted Vine_C (thick red circle) is not significantly different from other red circles but significantly different from those other LUCC types or transition represented by dark grey circles indicating higher $\mathrm{pH}$ for Vineyard soils, compared to mean $\mathrm{pH}$ under these LULC systems.

Figure 2. Diamond plots of analysis of variance of soil $\mathrm{pH}$ at different depths. Note that the circles on the right indicate pairwise comparison; the highlighted Vine_C (thick red circle) is not significantly different from other red circles, but significantly different from thick gray circles. See Table 1 for explanation of abbreviations. (a) Soil depth $(0-10 \mathrm{~cm})$; (b) soil depth $(10-20 \mathrm{~cm})$; (c) soil depth $(20-30 \mathrm{~cm})$; (d) soil depth $(40-50 \mathrm{~cm})$.

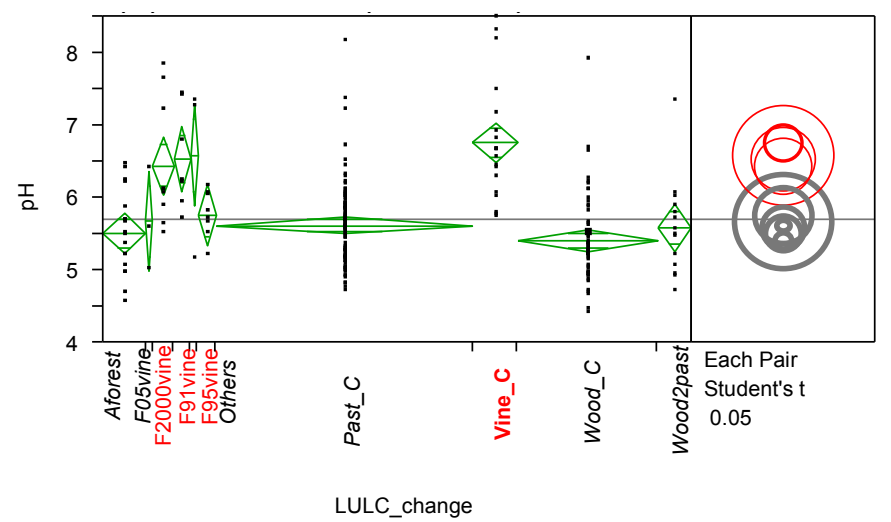

(a)

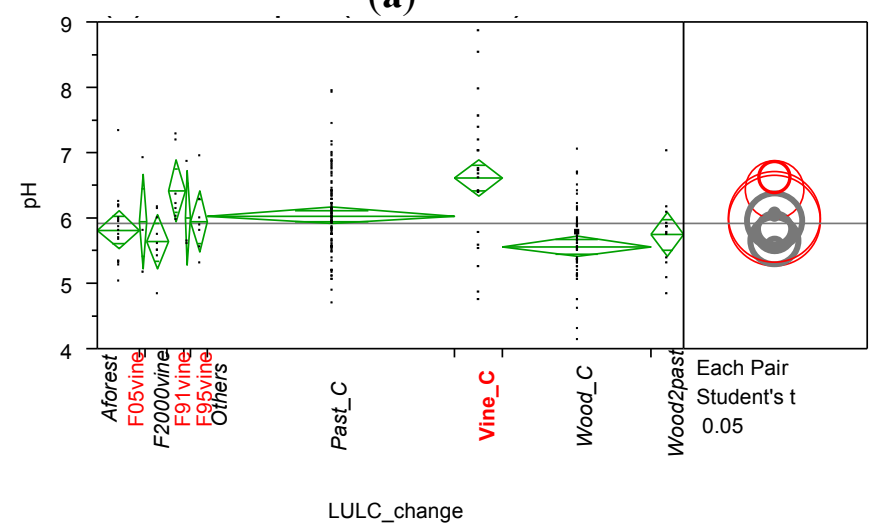

(c)

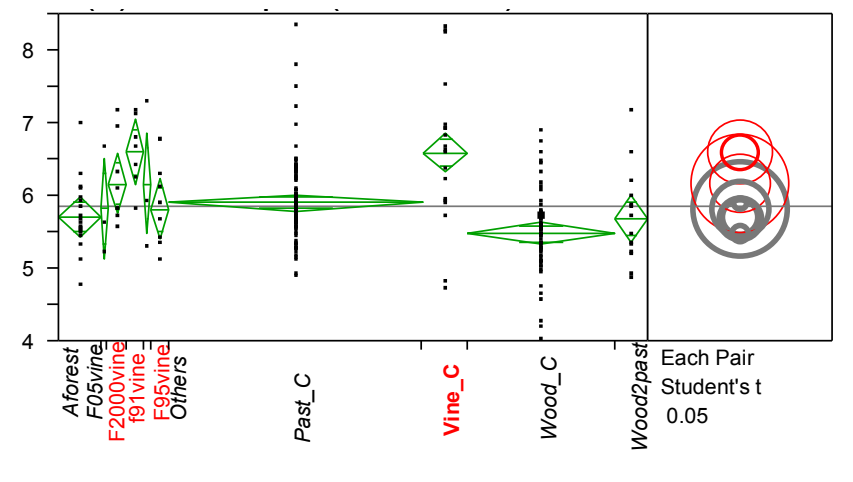

LULC_change

(b)

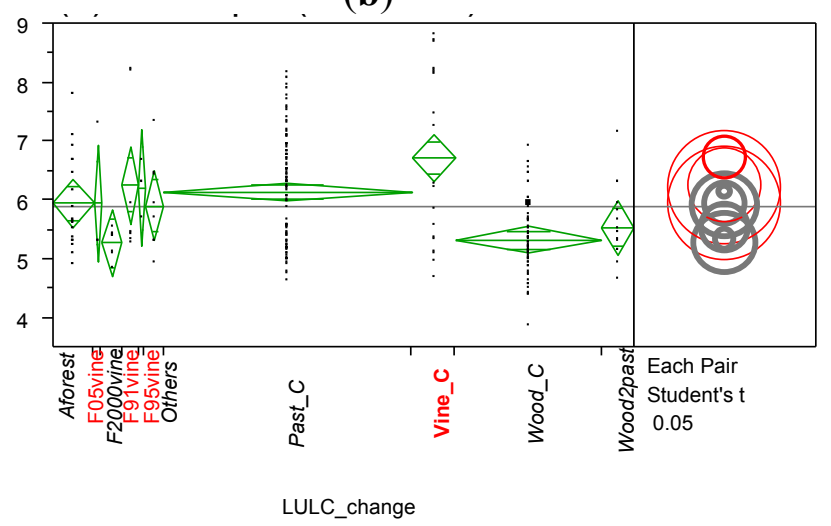

(d) 
Overall soil layers under Wood_C (Woodland consistency) had the lowest mean $\mathrm{pH}$ value followed by Aforest (other LULC categories converting to Woodland), and then by Wood2past (Area converted from Woodland to Pasture/scrubland) and Past_C (Figure 2). While the $\mathrm{pH}$ of land under the area that was converted to Vineyard was generally characterised by the mean $\mathrm{pH}$ values; i.e., lower than that under the Vine_C but higher than that under the other LULC categories (i.e., Woodland, Aforest and Wood2Past and Past_C).

The depth profiles of the mean $\mathrm{pH}$ under the three major LULC categories (Figure 3) indicate Vine_C is characterised by the highest $\mathrm{pH}$ values at all the depths followed by Past_C and then by Wood_C. This result is corroborated by the finding of Minasny and McBratney [42] who found that lands under viticulture have significantly larger than under non-viticulture lands, by about $0.5 \mathrm{pH}$ unit. The higher $\mathrm{pH}$ of under Vineyard could be due to either or both of the two following pathways:

(i) Neutralizing effect of Vineyard land use- this may be due to application of lime under vineyard cultivation [42].

(ii) Landforms which attracted cultivation of Vineyard originally had higher soil $\mathrm{pH}$.

As reported by Faine and others [14] the intensive grape-producing area is located where the acid buffering capacity is considered to be moderate, requiring 5.5 to $11 \mathrm{M}$ of $\mathrm{H}+$ to decline to 4.5. Therefore the second pathway is probably the dominant factor.

Figure 3. $\mathrm{pH}$ of soil under different land use and land cover (LULC) at varying depths. Note that: Wood_C $=$ Woodland consistency, Past_C $=$ Pasture/scrubland consistency, Vine_C $=$ Vineyard consistency.

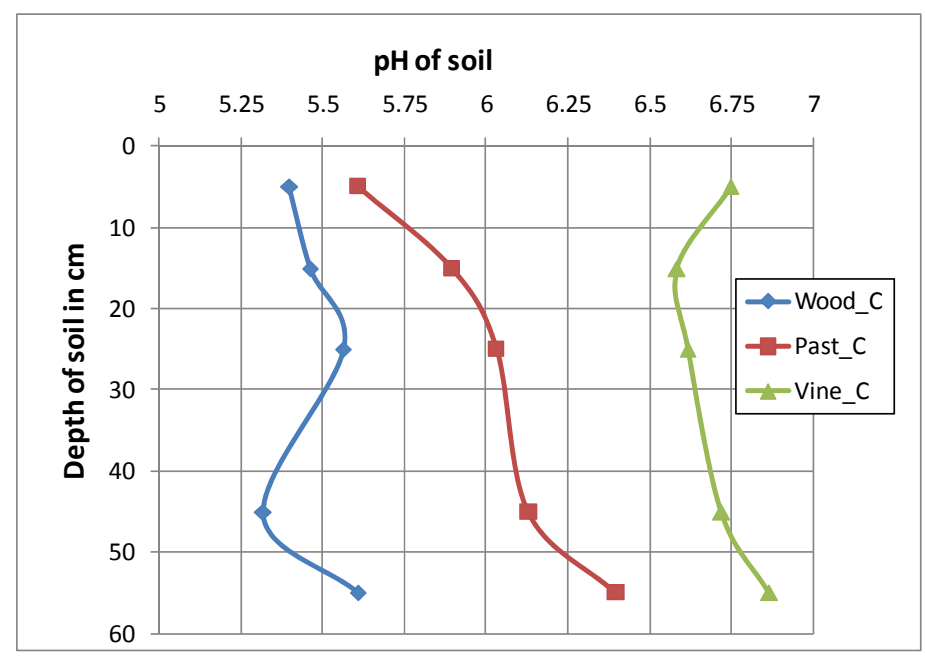

\subsection{Effect of LULC on Soil Salinity}

Salinity, as measured by EC, does not vary significantly under different LULC categories (Table 3). It is also interesting to note that land management practices under vineyard did not have significant impact on soil salinity level. However, Woodland consistency was found to have lower topsoil EC compared with the same values under other LULCs whereas in the case of the subsoil, Woodland has slightly higher EC compared to others. This is probably due to increased leaching of salts from the topsoil to the lower soil layers under forest, and/or due to preponderance of soil organic matter and hence higher 
microbial activity under forest soils compared to cultivated soils $[16,43]$. In the case of the layer just below the surface layer, there was no definite trend in EC across different LULC categories (Table 3).

Consistent with the above findings, the depth profiles of EC1:5 shown in Figure 4 indicate that the topsoil salinity is generally low. However, there is a distinctive increase of salt level for all LULC categories in the deeper soil layer $(>50 \mathrm{~cm})$. This may be due to provenance of salt from the parent material, and perhaps more importantly due to the leaching of salts from the upper soil layers caused by percolating water from rainfall and/or irrigation.

Table 3. Mean Electrical Conductivity (EC) $\left(\mathrm{dS} \cdot \mathrm{m}^{-1}\right)$ of soils under different land use and land cover (LULC) categories; values in brackets are the standard errors.

\begin{tabular}{|c|c|c|c|c|c|c|c|c|c|c|}
\hline $\begin{array}{c}\text { Soil Parameter } \\
\text { and Depth }\end{array}$ & $\begin{array}{c}\text { Wood_C } \\
n=60\end{array}$ & $\begin{array}{l}\text { Past_C } \\
n=108\end{array}$ & $\begin{array}{c}\text { Vine_C } \\
n=19\end{array}$ & $\begin{array}{c}\text { F91vine } \\
n=7\end{array}$ & $\begin{array}{c}\text { F95vine } \\
n=3\end{array}$ & $\begin{array}{l}\text { F2000vine } \\
\qquad \begin{array}{l}n=9 \\
\end{array}\end{array}$ & $\begin{array}{c}\text { F05vine } \\
n=3\end{array}$ & $\begin{array}{l}\text { Aforest } \\
n=18\end{array}$ & $\begin{array}{c}\text { Wood2past } \\
n=14\end{array}$ & $\begin{array}{l}\text { Others } \\
n=8\end{array}$ \\
\hline EC10 & $\begin{array}{l}139.88 \mathrm{c} \\
(23.39)\end{array}$ & $\begin{array}{l}156.66 \mathrm{~b} \\
(17.29)\end{array}$ & $\begin{array}{c}156.73 \mathrm{ab} \\
(41.22)\end{array}$ & $\begin{array}{c}141.93 \mathrm{abc} \\
(67.91)\end{array}$ & $\begin{array}{c}118.40 \mathrm{abc} \\
(103.74)\end{array}$ & $\begin{array}{c}126.27 \mathrm{bc} \\
(59.89)\end{array}$ & $\begin{array}{l}360.57 \mathrm{a} \\
(103.74)\end{array}$ & $\begin{array}{c}140.09 \mathrm{bc} \\
(42.35)\end{array}$ & $\begin{array}{c}148.44 \text { bc } \\
(48.02)\end{array}$ & $\begin{array}{c}138.00 \mathrm{bc} \\
(63.53)\end{array}$ \\
\hline EC20 & $\begin{array}{l}226.96 \mathrm{a} \\
(34.75)\end{array}$ & $\begin{array}{l}130.70 \mathrm{a} \\
(26.45)\end{array}$ & $\begin{array}{l}161.44 \mathrm{a} \\
(62.77)\end{array}$ & $\begin{array}{l}119.46 \mathrm{a} \\
(103.42)\end{array}$ & $\begin{array}{l}104.03 \mathrm{a} \\
(157.98)\end{array}$ & $\begin{array}{c}194.66 \mathrm{a} \\
(96.74)\end{array}$ & $\begin{array}{l}216.40 \mathrm{a} \\
(157.98)\end{array}$ & $\begin{array}{c}165.18 \mathrm{~cd} \\
(64.49)\end{array}$ & $\begin{array}{c}152.67 \mathrm{~cd} \\
(73.13)\end{array}$ & $\begin{array}{c}134.73 \mathrm{~cd} \\
(96.74)\end{array}$ \\
\hline EC30 & $\begin{array}{c}196.75 \mathrm{ab} \\
(29.65)\end{array}$ & $\begin{array}{c}196.62 \mathrm{~b} \\
(22.97)\end{array}$ & $\begin{array}{c}203.20 \mathrm{ab} \\
(52.63)\end{array}$ & $\begin{array}{c}135.01 \mathrm{ab} \\
(88.95)\end{array}$ & $\begin{array}{c}110.07 \mathrm{ab} \\
(135.88)\end{array}$ & $\begin{array}{c}254.48 \mathrm{ab} \\
(78.45)\end{array}$ & $\begin{array}{c}277.60 \mathrm{ab} \\
(135.88)\end{array}$ & $\begin{array}{c}279.58 \mathrm{a} \\
(55.47)\end{array}$ & $\begin{array}{c}155.43 \mathrm{ab} \\
(62.90)\end{array}$ & $\begin{array}{c}147.40 \mathrm{ab} \\
(88.95)\end{array}$ \\
\hline EC50 & $\begin{array}{c}407.56 \mathrm{a} \\
(39.90)\end{array}$ & $\begin{array}{c}314.83 \mathrm{~b} \\
(30.62)\end{array}$ & $\begin{array}{c}320.84 \mathrm{ab} \\
(72.66)\end{array}$ & $\begin{array}{c}271.61 \mathrm{ab} \\
(119.71)\end{array}$ & $\begin{array}{c}174.23 \mathrm{ab} \\
(182.86)\end{array}$ & $\begin{array}{c}397.59 \mathrm{ab} \\
(105.57)\end{array}$ & $\begin{array}{c}228.37 \mathrm{ab} \\
(182.86)\end{array}$ & $\begin{array}{c}372.57 \mathrm{a} \\
(74.65)\end{array}$ & $\begin{array}{c}368.33 \mathrm{ab} \\
(84.65)\end{array}$ & $\begin{array}{c}277.06 \mathrm{ab} \\
(111.98)\end{array}$ \\
\hline ECdeep & $\begin{array}{c}686.65 \mathrm{a} \\
(66.16)\end{array}$ & $\begin{array}{c}610.19 \mathrm{ab} \\
(50.13)\end{array}$ & $\begin{array}{c}477.74 \mathrm{ab} \\
(119.51)\end{array}$ & $\begin{array}{c}425.11 \mathrm{ab} \\
(196.89)\end{array}$ & $\begin{array}{c}189.80 \mathrm{ab} \\
(300.76)\end{array}$ & $\begin{array}{l}353.15 b \\
(184.18)\end{array}$ & $\begin{array}{c}224.27 \mathrm{ab} \\
(300.76)\end{array}$ & $\begin{array}{l}714.08 \mathrm{a} \\
(126.34)\end{array}$ & $\begin{array}{l}622.49 \mathrm{a} \\
(138.22)\end{array}$ & $\begin{array}{c}443.51 \mathrm{ab} \\
(196.89)\end{array}$ \\
\hline
\end{tabular}

Note: Comparisons are done across the rows based on log-transformed data. Levels not connected by same superscript letter are significantly different. Also note: Wood_C $=$ Woodland consistency, Past_C $=$ Pasture/scrubland consistency, Vine_C $=$ Vineyard Consistency, F91vine = converted Vineyard between 1985 and 1991, F95vine = converted Vineyard between 1991 and 1995 , F2000vine $=$ converted Vineyard between 1995 and 2000, and F05vine $=$ converted Vineyard between 2000 and 2005. Aforest $=$ converted Woodland, Wood2past $=$ Converted Pasture/scrubland from Woodland. Others $=$ other than previously stated. $\mathrm{EC} 10=\mathrm{EC}$ of soil at a depth of 0-10 $\mathrm{cm}, \mathrm{EC} 20=\mathrm{EC}$ of soil at a depth of 10-20 $\mathrm{cm}, \mathrm{EC} 30=\mathrm{EC}$ of soil at a depth of $20-30 \mathrm{~cm}$, EC50 $=$ EC of soil at a depth of $40-50 \mathrm{~cm}$ and ECdeep $=$ EC of soil at a depth $>50 \mathrm{~cm}$.

The foregoing discussion (i.e., higher level of salinity of subsoil in comparison to upper layers) is corroborated by the work of Taylor [38] who reported that subsoil EC influenced Vineyard performance in Pokolbin wine-producing region, based on comparison of EC and NDVI maps of the region. The high amount of salt in the soil solution probably impacted on viticultural production systems (overall concentration of soluble salts) or sodicity (the relative concentration of sodium to magnesium and calcium). Similarly, Fitzpatrick et al. [44] and Cass et al. [45] reported that salt-affected soils, especially those associated with sodic soils are a major threat to many viticultural/agriculture production systems in southern Australia. Faine et al. [14] also reported occurrence of moderate to high salinity in a large area in the northwest region of the study area, the soils of which were found to be predominantly sodic. However, in contrast to all these findings, this study shows soil EC as below the hazardous level of salinity $\left(4 \mathrm{dS} \cdot \mathrm{m}^{-1}\right.$ or $\left.4000 \mu \mathrm{S} \cdot \mathrm{cm}^{-1}\right)$ even at the deeper sub-soil depths $(>50 \mathrm{~cm})$, which in our study have higher EC than the upper soil layers. Thus our findings here indicate that soil salinity is not a problem under cultivation and/or management practices. In fact, the local farmers group called Polkobin Irrigation District has an ongoing salt 
monitoring system for irrigation water; it has installed an EC measuring device at many of the river pumping stations, which are programmed to stop pumping river water when the EC reaches a certain critical level [14]. This might have prevented or delay the rise of soil EC.

Figure 4. Salinity (EC $=$ Electrical Conductivity) depth profiles of soil under different Land use land cover. Note that: Wood_C $=$ Woodland consistency, Past_ $=$ Pasture/scrubland consistency, Vine_C $=$ Vineyard Consistency.

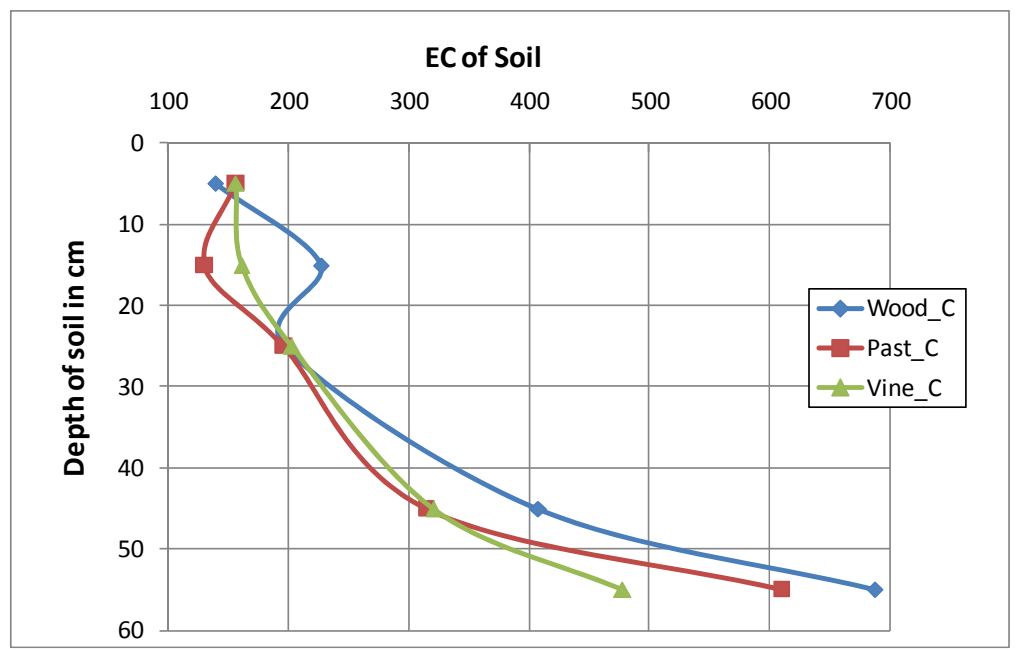

\subsection{Interrelationships of Soil Quality Indicators with Environmental Covariates}

Ecosystems are complex consisting of many interacting biotic and abiotic components. Multivariate ordination techniques such as Principal Component Analysis (PCA), CA and CCA have advantage over ANOVA as they enable the inclusion of numerous target variables in the analysis and, thus highlight their associations with the predictor variables. A useful outcome of these multivariate techniques is the biplot, which is an extension of the ordination diagram, in which the properties of the columns of the matrix (the variables analysed) are overlain on top of the main ordination diagram in order to highlight the relationships between the two sets of data (the target attributes and the predictor variables). The biplots rapidly allow the user to explore which target attributes and/or predictor variables are strongly associated since proximity implies close association.

In order to understand the ordination diagram, each arrow in biplots represent a predictor variable which determines the direction relative to the two axes in the diagram (Figure 5); soil attributes ( $\mathrm{pH}$ and EC), as represented by points, are projected onto each of the axes. The lengths of the vectors and angles between them are more important rather than their inter-point distances $[18,22,46]$. The predictor variables with long arrows, closer to a given ordination axis, are more strongly correlated with the ordination axes than those with short arrows; thus those represented by long arrows are more closely related to the pattern of landscape variation shown in the ordination diagram. Thus the ordination diagram characteristically shows the main pattern of variation in soil variables as accounted for by the predictor variables, in this case, LULC categories and systems and selected landform attributes.

As unimodal models have been considered as more general than monotonic [18], this study opted for analysing the data using CA and its canonical counterpart, CCA. Both CA and CCA biplots convey 
similar overall information about the complex interrelationships, although the effect of the predictor variables is less prominent in the CA biplot in comparison to that shown by the CCA biplot (Figure 5). The biplot of CCA (Figure 5b) demonstrates that Vine_C (Vineyard consistency) is more closely associated with slope; the arrows (predictor variables) pointing roughly in the same direction, indicating high positive correlation, while arrows pointing in the opposite directions imply high negative correlation and that arrows crossing at right angle indicate zero correlation [21,22,32]. This is expected, as lands characterised by sloppy terrain are preferred for vineyards because of their advantage of better drainage and a reduced risk of water logging [38]. Unlike the results of ANOVA, the CCA biplots shows no evidence of a close association of $\mathrm{pH}$ with Vine_C, rather elevation is evidently more closely association with $\mathrm{pH}$ than Vine_C. Thus, the higher the elevation the larger is the $\mathrm{pH}$ level, i.e., the more alkaline the soils become, especially in the topsoil layers. In contrast, Wood_C is negatively associated with $\mathrm{pH}$, indicating soil under Woodland to be more acidic compared to soils under other LULC categories (Pasture/scrubland and Vineyard).

Figure 5. Biplots from (a) Correspondence analysis and (b) Canonical correspondence analysis. Note that: Wood_C $=$ Woodland consistency, Past_C $=$ Pasture/scrubland consistency, Vine_C $=$ Vineyard Consistency, Elev $=$ Elevation, CTI $=$ Compound topographic index, $\mathrm{pH} 10=\mathrm{pH}$ of soil at a depth of $0-10 \mathrm{~cm}, \mathrm{pH} 20=\mathrm{pH}$ of soil at a depth of $10-20 \mathrm{~cm}, \mathrm{pH} 30=\mathrm{pH}$ of soil at a depth of $20-30 \mathrm{~cm}, \mathrm{pH} 50=\mathrm{pH}$ of soil at a depth of $40-50 \mathrm{~cm}$ and $\mathrm{pHdeep}=\mathrm{pH}$ of soil at a depth $>50 \mathrm{~cm}$; EC10 $=\mathrm{pH}$ of soil at a depth of $0-10 \mathrm{~cm}, \mathrm{EC} 20=\mathrm{pH}$ of soil at a depth of $10-20 \mathrm{~cm}, \mathrm{EC} 30=\mathrm{pH}$ of soil at a depth of 20-30 $\mathrm{cm}, \mathrm{EC} 50=\mathrm{EC}$ of soil at a depth of $40-50 \mathrm{~cm}$ and pHdeep $=\mathrm{EC}$ of soil at a depth $>50 \mathrm{~cm}$.

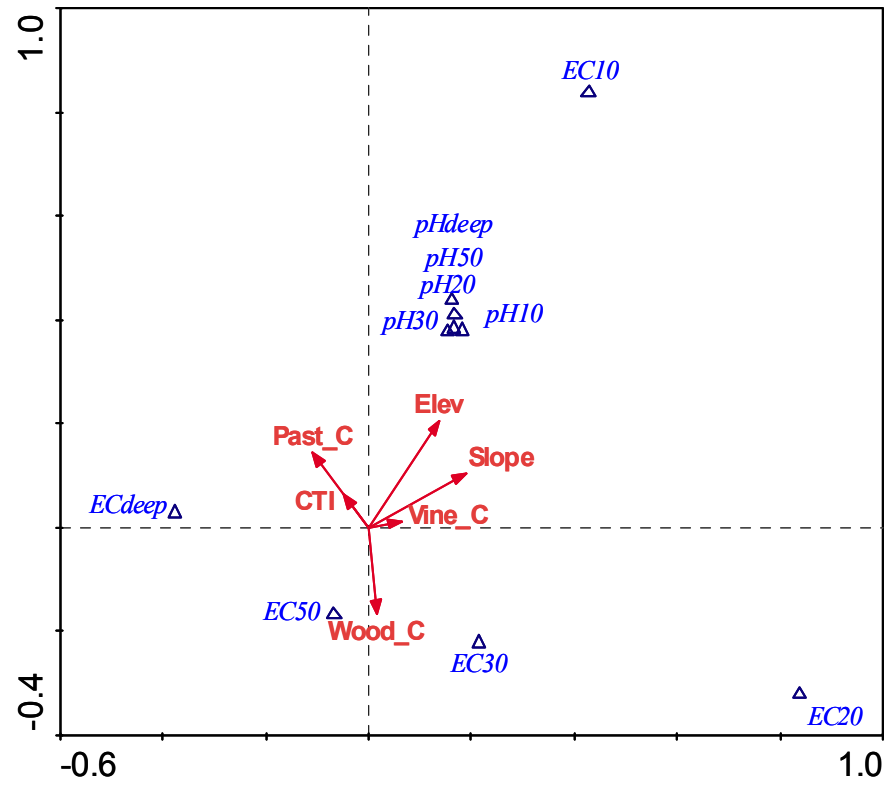

(a)

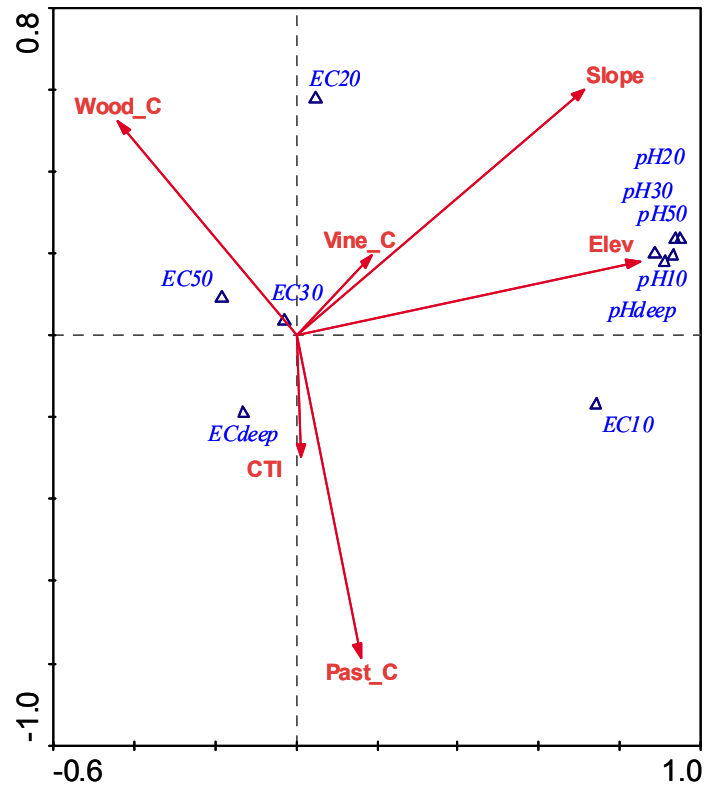

(b)

The influence of LULC types and landform attributes on salinity is also well illustrated by the CCA biplot (Figure 5b), which shows EC values at different layers spread out in the biplot. This is indicative of how EC at different layers were variably associated with the different LULC types. As such, 
Wood_C has negative association with topsoil EC (i.e., EC10) but is somewhat more closely associated with EC50 and EC30. The large values of soil EC at lower depth in contrast to the lesser values of EC and lower values of $\mathrm{pH}$ in the topsoil under Woodland LULC type may be attributable to microclimate of forest flora which may have increased organic matter and soil microflora especially at surface layer [43,47]. As demonstrated by the biplot of CCA (Figure 5b) CTI and Past_C have somewhat closer association with ECdeep which is logical in the sense that soluble salts would have leached to the lower depths. Additionally, the larger values of CTI are usually found in the lower parts of watersheds and convergent hollow areas associated with soils with low hydraulic conductivity or areas of low slope [42].

Generally this study found a few discrepancies between CA and CCA:

In CCA, the first ordination axis is largely due to elevation gradient and the second axis is largely accounted for by CTI, which mainly explains the variation in Pasture/scrubland, while in CA, the first ordination axis is mainly accounted for by Vineyard followed by slope and second ordination axis is largely explained by Woodland.

As the length of the arrow quantifies the rate of change in that direction, these two methods indicate differences in variation in the included variables that differ along the environmental gradient. Again, CCA is constrained to environmental gradient rather than the real value.

Table 4 shows the eigenvalues and variance accounted for by the first four axes of CA and CCA. The variance accounted for by the first two axes of CA (i.e., represented by the biplots) increased from $75.5 \%$ in CA to $82.2 \%$ in case of CCA. The soil-environment correlation also improved slightly from 0.514 for CA to 0.545 for CCA.

Table 4. Variance accounted for by the first four axes of correspondence analysis (CA) and canonical correspondence analysis (CCA). (Sum total eigen value for CA is 0.4 and for CCA is 0.021 ).

\begin{tabular}{ccccc}
\hline Axis & Eigenvalue $(\boldsymbol{\lambda})$ & \% of Total $\boldsymbol{\lambda}$ & $\mathbf{R}$ (Soil, Environment) & $\begin{array}{c}\text { Cumulative \% Variance } \\
\text { (Soil, Environment) }\end{array}$ \\
\hline \multicolumn{5}{c}{} \\
\hline 1 & 0.161 & 40.3 & Correspondence analysis \\
2 & 0.099 & 24.8 & 0.212 & 33.5 \\
3 & 0.083 & 20.8 & 0.302 & 75.5 \\
4 & 0.044 & 11 & 0.184 & 88.5 \\
& & Canonical correspondence analysis & 94.3 \\
1 & 0.011 & 52.4 & 0.313 & \\
2 & 0.007 & 33.3 & 0.232 & 89.5 \\
3 & 0.003 & 14.3 & 0.187 & 95.2 \\
4 & 0.001 & 4.8 & 0.146 & 99.8 \\
\hline
\end{tabular}

Ordination provides information as to whether important environmental variables have been overlooked: an important variable has been definitely been missed if there is no relation between the mutual positions of the sites in the ordination diagram and the measured environmental variables [23].

In our study, the significantly higher $\mathrm{pH}$ of Vineyard areas, as observed from the ANOVA, can be due to cultivation of Vineyards in the upper slopes which has close association with higher $\mathrm{pH}$. 
Vineyard cultivation is preferred in areas of slightly steep slopes and a higher elevation rather than the lower part of watershed in order to have katabatic drainage of air, in addition to the requirement of good water drainage and reduced risk of water logging [38]. Therefore, higher $\mathrm{pH}$ of Vineyard soils must have resulted due to cultivation of Vineyard in mid- to upper- slopes apart from lime application under Vineyard paddocks. This outcome was missed by ANOVA alone, as the latter technique could not examine the complex relationship under multiple sets of factors.

\section{Conclusions}

A key finding of this study is that soils under Vineyard were found to have significantly higher $\mathrm{pH}$ and hence increased alkalinity, which may be attributable to land use practices under Vineyard cultivation, and/or also due to inherent soil properties or landform that attracted Vineyard cultivation. However, there is no significant effect of land use and land cover (LULC) on soil salinity, indicating Vineyard soils were not as degraded in terms of soil salinity as have been published [11]. Using a robust multivariate ordination technique of canonical correspondence analysis (CCA), the complex interrelationships revealed that elevation had the dominant influence on $\mathrm{pH}$ in comparison to Vineyard cultivation, while Woodland had the closer positive association with subsoil salinity, but negative association with topsoil salinity and acidity. Thus, ordination analysis in addition to analysis of variance (ANOVA) opens up our mind in understanding the complex but minute variation in acidity and salinity caused by LULC change in relation to the effect of other landform attributes.

\section{Acknowledgments}

We acknowledge the support of the Australian Government for providing an Endeavour International Postgraduate Research Scholarship to the first author to pursue this study and the Ministry of Agriculture Development of Nepal for granting her study leave. We also acknowledge the contribution of soil data by Nathan Odgers, of the University of Sydney. Work performed by the editorial office and two anonymous reviewers are greatly appreciated.

\section{Author Contributions}

Both authors of this paper contributed to the design, data analysis and the writing of the manuscript.

\section{Conflicts of Interest}

The authors declare no conflict of interest.

\section{References}

1. Lambin, E.F.; Turner, B.L.; Geist, H.J.; Agbola, S.B.; Angelsen, A.; Bruce, J.W.; Coomes, O.T.; Dirzo, R.; Fischer, G.; Folke, C.; et al. The causes of land-use and land cover change: Moving beyond the myths. Glob. Environ. Chang. 2001, 11, 261-269.

2. Foley, J.A.; Defries, R.; Asner, G.P.; Barford, C.; Bonan, G.; Carpenter, S.R.; Chapin, F.S.; Coe, M.T.; Daily, G.C.; Gibbs, H.K.; et al. Global consequences of land use. Science 2005, 309, $570-574$. 
3. Braimoh, A.K.; Vlek, P.L.G. The Impact of Land Use on Soil Resources. In Land Use and Soil Resources; Braimoh, A.K., Vlek, P.L.G., Eds.; Springer Science Publication: Stockholm, Sweden, 2008; pp. 1-7.

4. Brian, H. Current Practices and Extension on Acid Soils in NSW. Available online: http://www.anra.gov.au/topics/soils/acidification/index.html (accessed on 4 December 2009).

5. Singh, B.; Odeh, I.O.A.; McBratney, A.B. Acid buffering capacity and potential acidification of cotton soils in northern New South Wales. Aust. J. Soil Res. 2003, 41, 875-888.

6. Australian Agriculture Assessment Report. Available online: http://www.anra.gov.au/topics/ soils/pubs/national/agriculture_contents.html (accessed on 4 December 2009).

7. Rengasamy, P. World salinization with emphasis on Australia. J. Exp. Bot. 2006, 57, 1017-1023.

8. Pannell, D.J. Dryland salinity: Economic, scientific, social and policy dimensions. Aust. J. Agric. Resour. Econ. 2001, 45, 517-546.

9. Rengasamy, P. Transient salinity and subsoil constraints to dryland farming in Australian sodic soils: An overview. Aust. J. Exp. Agric. 2002, 42, 351-361.

10. Australian Natural Resource Atlas. Available online: http://www.anra.gov.au/topics/salinity/pubs/ national/salinity_aus.html (accessed on 4 December 2009).

11. National Dryland Salinity Program. Breaking Ground: Key Findings from 10 Years of Australia's National Dryland Sality Program; Land and Water Australia: Canberra, ACT, Australia, 2004; p. 72 .

12. James, D. Salinity Management in the Hunter, Case Study Two in Water Quality Management: Five Case Studies; Coastal Zone Inquiry, Resources Assessment Commission: Canberra, ACT, Australia, 1993.

13. Fisher, R.J. Local knowledge of dryland salinity in the Hunter Valley, Australia. Indig. Knowl. Dev. Monit. 1995, 3, 13-14.

14. Faine, J.N.; McBratney, A.; Taylor, J. HWCPIDGIS: A Preliminary Environmental Geographic Information System for the Hunter Wine Country Private Irrigation District. A Draft Report 2001; Australian Centre for Precision Agriculture, University of Sydney: Darlington, NSW, Australia, 2006.

15. Creelman, R.A.; Cooke, R.; Simons, M. Salinity and Resource Management in the Hunter Valley. In Proceedings of 29th Newcastle Symposium, Advances in the Study of the Sydney Basin, Newcastle, NSW, Australia, 6-9 April 1995.

16. Braimoh, A.K.; Vlek, P.L.G. The impact of land cover change on soil properties in northern Ghana. Land Degrad. Dev. 2004, 15, 65-74.

17. Gong, J.; Chen, L.; Fu, B.; Huang, Y.; Huang, Z.; Peng, H. Effect of land use on soil nutrients in the Loess Hilly Area of the Loess Plateau, China. Land Degrad. Dev. 2006, 17, 453-465.

18. Odeh, I.O.A.; Chittleborough, D.J.; McBratney, A.B. Elucidation of soil-landform interrelationships by canonical ordination analysis. Geoderma 1991, 49, 1-32.

19. Taghizadeh-Mehrjardi, R.; Minasny, B.; Sarmadian, F.; Malone, B.P. Digital mapping of soil salinity in Ardakan region, central Iran. Geoderma 2014, 213, 15-28.

20. Bilgili, A.V. Spatial assessment of soil salinity in the Harran Plain using multiple Kriging techniques. Environ. Monit. Assess. 2013, 185, 777-795.

21. Shaw, P.J.A. Basic Concepts in Ordination. In Multivariate Statistics for the Environmental Sciences; Hodder Arnold, Holder Headline Group: London, UK, 2003; Chapter 4, pp. 73-82. 
22. Ter Braak, C.J.F. Canonical correspondence analysis: A new eigenvector technique for multivariate direct gradient analysis. Ecology 1986, 67, 1167-1179.

23. Ter Braak, C.J.F. Ordination. In Data Analysis in Community and Landscape Ecology; Jongman, R.H.G., Ter Braak, C.J.F., van Tongeren, O.F.R., Eds.; Press Syndicate of the University of Cambridge: Cambridge, UK, 1995; Chapter 5, pp. 91-173.

24. Palmer, M.W. Putting things in even better order: The advantages of canonical correspondence analysis. Ecology 1993, 74, 2215-2230.

25. Graffelman, J.; Tuft, R. Site scores and conditional biplots in canonical correspondence analysis. Environmetrics 2004, 15, 67-80.

26. Zhang, J.; Oxley, R.R.B. A comparison of three methods of multivariate analysis of upland grasslands in North Wales. J. Veg. Sci. 1994, 5, 71-76.

27. Salles, J.F.; van Veen, J.A.; van Elsas, J.D. Multivariate analyses of Burkholderia species in soil: Effect of crop and land use history. Appl. Environ. Microbiol. 2004, 70, 4012-4020.

28. Stèphane, D.; Sonia, S.; François, D. Spatial ordination of vegetation data using a generalization of Wartenberg's multivariate spatial correlation. J. Veg. Sci. 2008, 19, 45-56.

29. Glass, G.V.; Peckham, P.D.; Sanders, J.R. Consequences of failure to meet assumptions underlying the fixed effects analyses of variance and covariance. Rev. Educ. Res. 1972, 42, 237-288.

30. Bentler, P.M. Covariance structure analysis-Statistical practice, theory and directions. Annu. Rev. Psychol. 1996, 47, 563-592.

31. Kenkel, N.C.; Derksen, D.A.; Thomas, A.G.; Watson, P.R. Review: Multivariate analysis in weed science research. Weed Sci. 2002, 50, 281-292.

32. Qiu, Y.; Fu, B.; Wang, J.; Chen, L. Soil moisture variation in relation to topography and land use in a hillslope catchment of the Loess Plateau, China. J. Hydrol. 2001, 240, 243-263.

33. Fu, B.J.; Zhang, Q.J.; Chen, L.D.; Zhao, W.W.; Gulinck, H.; Liu, G.B.; Yang, Q.K.; Zhu, Y.G. Temporal change in land use and its relationship to slope degree and soil type in a small catchment on the Loess Plateau of China. Catena 2006, 65, 41-48.

34. Manandhar, R.; Odeh, I.; Ancev, T. Improving the accuracy of land use and land cover classification of Landsat data using post-classification enhancement. Remote Sens. 2009, 1, 330-344.

35. Odgers, N.P. Bottom-up Digital Soil Mapping. Ph.D. Thesis, The University of Sydney, Darlington, Australia, 2010; Unpublished.

36. Minasny, B.; McBratney, A.B. A conditioned Latin hypercube method for sampling in the presence of ancillary information. Comput. Geosci. 2006, 32, 1378-1388.

37. McKenzie, N.J.; Gessler, P.E.; Ryan, P.J.; O’Connell, D.A. The Role of Terrain Analysis in Soil Mapping. In Terrain Analysis: Principles and Applications; Wilson, J.P., Gallant, J.C., Eds.; John Wiley \& Sons, Inc.: New York, NY, USA, 2000; Chapter 10, pp. 245-265.

38. Taylor, J.A. Digital Terroirs and Precision Viticulture: Investigations into the Application of Information Technology in Australian Vineyards. Ph.D. Thesis, University of Sydney, Darlington, NSW, Australia, 2004; p. 255.

39. Gallant, J.C.; Wilson, J.P. Primary Topographic Attributes. In Terrain Analysis: Principles and Applications; Wilson, J.P., Gallant, J.C., Eds.; John Wiley \& Sons, Inc.: New York, NY, USA, 2000; Chapter 3, pp. 51-85. 
40. Ter Braak, C.J.F.; Šmilauer, P. CANOCO Reference Manual and CanoDraw for Windows User's Guide: Software for Canonical Community Ordination (Version 4.5); Microcomputer Power: Ithaca, NY, USA, 2002; p. 500.

41. JMP Statistics and Graphics Guide. Release 6; SAS Institute Inc.: Cary, NC, USA, 2005.

42. Minasny, B.; McBratney, A.B. Spatial prediction of soil properties using EBLUP with the Matern covariance function. Geoderma 2007, 140, 324-336.

43. Khresat, S.; Al-Bakri, J.; Al-Tahhan, R. Impacts of land use/cover change on soil properties in the Mediterranean region of Northwestern Jordan. Land Degrad. Dev. 2008, 19, 397-407.

44. Fitzpatrick, R.W.; Wright, M.J.; Stevens, R.M. Drainage, Sodicity and Related Problems of Vineyard Soils. In Proceedings of the Eighth Australian Wine Industry Technical Conference, Melbourne, Australia, 25-29 October 1992; pp. 38-44.

45. Cass, A.; Walker, R.R.; Fitzpatrick, R. Vineyard Soil Degredation by Salt Accumulation and the Effect on the Performance of the Vine. In Proceedings of the Ninth Australian Wine Industry Technical Conference, Adelaide, SA, Australia, 16-19 July 1995; pp. 153-160.

46. Greenacre, M. Correspondence Analysis Biplots. In Correspondence Analysis in Practice; Chapman \& Hall/CRC Taylor \& Francis Group: London, UK, 2007; Chapter 13, pp. 97-104.

47. Jia, G.; Wang, C.; Wang, G. Microbial biomass and nutrients in soil at the different stages of secondary forest succession in Ziwulin, Northwest China. For. Ecol. Manag. 2005, 217, 117-125.

(C) 2014 by the authors; licensee MDPI, Basel, Switzerland. This article is an open access article distributed under the terms and conditions of the Creative Commons Attribution license (http://creativecommons.org/licenses/by/3.0/). 